\title{
Portrayal of Indian Army in Kashmir Media: An Analytical Study of Local Newspapers
}

\author{
Pardeep Singh Bali \\ $\mathrm{PhD}$ scholar at the department of Journalism and Mass communication, Punjabi University Patiala- \\ Punjab-India
}

\begin{abstract}
Kashmir has remained at the crossroads of violence since the Britishers left India divided into two dominions. The Kashmir conflict is one of the longest running conflicts. Although it can be argued that six decades of conflict is rather modest in an historical perspective, the conflict is frequently portrayed in terms of 'enduring' and 'protracted'. Starting as a bilateral dispute over territorial entitlement stemming from India's claim of control to the entire state of Jammu and Kashmir, and Pakistan's irredentist claim to the Indian controlled of Kashmir, the conflict has evolved beyond interstate level. With the increasingly complex and multidimensional nature, the conflict has become increasingly ideological on all sides. Amid this multidimensional nature of conflict, the role of Indian army becomes significant, which according to the Guinness Book of World Record, their presence makes Kashmir the 'most militarized zone' on the planet earth. This research papers intends to study the portrayal of Indian army in the local media of Kashmir, especially print media. It has been seen that the local print media do not put Indian Army in a good light. They always exaggerate and accuse Indian army of human right violations, while as under reports the social work carried by the army.
\end{abstract}

Keywords: Kashmir, conflict, Indian Army, portrayal, media.

\section{INTRODUCTION}

Jammu and Kashmir, once only known for its picturesque beauty, continues to have a mention in the Guinness Book of World Records as the 'most militarized zone and the longest pending dispute on the planet earth.

The Kashmir has made its place in the facts book for four reasons and all the reasons are linked to the pending dispute. Kashmir is the World's highest battle field and largest militarized zone. It has also the highest number of military bases in the world and finally the lengthiest speech in the United Nations was given over the dispute of Kashmir.

As India and Pakistan was established as two separate states in 1947, the 'Indian Independence Act' contained a provision allowing 562 princely states to decide whether to join India or Pakistan. Most states decided to remain within its respective national domains, however, three states opted for independence, among them Jammu and Kashmir. A key foundation for the conflict can be traced to the region's exceptional ethno-religious diversity. Being made up by four districts, Kashmir which is predominantly Muslim, Leah and Kargil, mostly Muslim and Buddhist and Jammu, predominantly Hindu, the area is fundamentally conflict prone (Ganguly, 1997, 39). Although having a predominantly Muslim population, the region was ruled by the Hindu Maharaja Hari Singh who strongly favoured Kashmiri independence (Blank, 1999, 39). However, following an attempted invasion by Pakistani tribal forces, Singh; hoping to forestall an uprising and a Pakistani-backed incursion saw no option but to join India (Ganguly 2006) (Paul, 2005, 7-8). This was unacceptable for the Pakistani nationalist government of President Mohammed Ali Jinnah who considered the absorption of Kashmir as vital. Arguing that Pakistan would be 'incomplete' without it, Jinnah decided to send soldiers to the region. On the contrary, Indian nationalists view the integration of Kashmir as a demonstration that India could be a nation where all faiths could live together under the aegis of a secular state (Ganguly, 1997, 8-10). Thus, losing Kashmir would for Indian nationalists undermine its secular identity.

As both countries decided to send soldiers, the dispute escalated into a short war, ending with a ceasefire agreement in late 1948, leaving Kashmir divided into two-third under Indian rule and the rest 
under Pakistan and China (Paul, 2005, 8). The 1949 settlement established the ceasefire line today known as the 'line of control' (LoC), which remained UN monitored until 1972. As a result of the settlement, India gained control of an area of approximately 10 million people in the regions of Kashmir Valley, Jammu and Ladkah while Pakistan seized control of Azad Kashmir and some sparsely populated regions in the north, altogether about 3 million people (Bose, 2003, 2). Based on evolutionary concept framed by Hensel; a first confrontation ending in a stalemate and dissatisfaction among both is likely to increase distrust and hostility (Paul, 2005, 30). In the Kashmir conflict, this was indicated by neither of the parties accepting the LoC as border. Furthermore, numerous skirmishes and two additional wars (1965 and 1999) over Kashmir, and another three over related matters in (1971-72, 1990 and 2001) has only marginally altered the LoC (Ganguly, 1997, 3).

While Pakistan have attempted to annex territory justified on ethnic or historical grounds and India sought to preserve status quo, both countries have largely overlooked the Kashmiris themselves (Paul, 2005, 203 / Schofield, 2000, 228). Despite enjoying a special constitutional position under article 370, e.g. being allowed its own constitution and elections to state legislature held under the provision of the Indian constitution, the actual extent of the autonomy has proven highly volatile (Dossani/Rowen, 2005, 240). Growing Kashmiri nationalism in the 1980s combined with grievances over perceived disproportionate representation in the regional parliament were efficiently utilized by militant leaders to mobilize disillusioned youth for armed struggle for increased political rights. From 1989 and onwards, this grievance erupted in violent separatist movement erupted id in this region. The 'Jammu and Kashmir Liberation front (JKLF)' leaded uprising caused sporadic strikes and demonstrations, reaching its peak the December 1989 kidnapping of the Indian Minister for home affairs' daughter (Ganguly, 1997, 1).

The introduction of new actors, and particularly the secessionist movements significantly changed the military and political character of the conflict, thus creating a multidimensional and highly complex conflict (Bose, 2003, 4). This efficiently moved the conflict beyond state level, and since then it has been the Kashmiris that have done most of the fighting and suffered the highest losses. At the moment there is believed to be around 10 different separatist operating in Jammu and Kashmir, ranging from terrorist groups to non-violent organizations. Although only a handful of these have political credibility, they highlight the plurality of opinions existing among the Kashmiris (Krepon, 2004, 152).

Failing to acknowledge the changing nature of the conflict, Indian policy makers approached the Kashmir issue from a traditional counterinsurgency perspective. However, as observed by Kilcullen; the nature of modern counter-insurgencies tend to consist of multiple competing insurgent forces, each seeking to maximize their survivability and influence (Kilcullen, 2006, 122). By deploying four hundred thousand security forces from its army as well as paramilitary forces, India did not only raise the share of annual administration costs allocated to security. Fighting an unidentifiable enemy caused the Indian army to suffer high causality rates in their efforts of maintaining control of the Kashmir. After six years of fighting, counter-insurgency operations had claimed the lives of at least 15,000 people. Furthermore, by placing the state under emergency rule in July 1990, India granted its security forces substantial immunity as well as introduced judicial and extrajudicial punishments such as laws enabling the law enforcement agencies to keep suspect under custody for up to a year (Ganguly, 1997, 2) / (Wirsing, 1994, 156). Fuelled by severe accusations of torture by the police, India increasingly failed to win the battle for winning 'hearts and minds'. Rather than running a successful counterinsurgency campaign, Indian policies generated an increasing sentiment of alienation and strong refusal of integration with India, particularly in the Kashmir valley (Bose, 2003, 195).

An important characteristic of asymmetric conflicts is the potential of third parties of third parties may change conflict structure in terms of communication as well as balance of power (Ramsbotham et. al, 2005, 18). Following the 1971 war that resulted in the liberation of Bangladesh (before then EastPakistan); India emerged as the dominant power of the subcontinent. In addition of being a symbolic, psychological and material blow, the loss of East-Pakistan undermined Pakistan's irredentist ethnonationalist claim of Kashmir (Ganguly, 1997, 59-60). However, instead of adjusting its goals, Pakistan adjusted its strategies (Paul, 2005, 106). Despite Hagerty pointing out that Hindus and Muslims have coexisted on the sub-continent for centuries without substantial violence, and Singer's observation that ethno-cultural dissimilarities are rarely able to produce war (ibid. 86); it is worth noticing Mac Ginty's point of ethnicity as a powerful mobilization tool that can be very useful in order to exploit existing conflicts (Mac Ginty, 2008, 71-72). Suddenly presenting Pakistan with an 
opportunity to revenge the 1971 humiliation and undermine Indian control of Kashmir, Pakistani leaders decided to aid rebels by providing weapons, training and sanctuaries (Ganguly 2006). Furthermore, being able to obtain relative sophisticated and effective weapons and guerrilla training from the Pakistani army's Inter-Service Intelligence (ISI), Kashmiri militants efficiently outgunned local police forces and in short time paralyzed the state's law and order machinery. Uplifted by the initial success of the independence movement, Pakistan's in the early 1990s gradually diverted its assistance towards Islamic militants seeking accession to Pakistan. As local Kashmiris predominantly subscribed to a secular or a Muslim Kashmiri view of their identity, major beneficiaries such as the Hizbul Mujahedin enjoyed very limited popular support. Nevertheless, the introduction of foreign jihadists and mercenaries, many of whom with experience from Afghanistan, further escalated the war, but also decreased popular support for the militant movement (Dossani/Rowen, 2005, 251-253).

As pointed out by Jabri, third parties can through for instance facilitation of communication, provision of resolution alternatives and use concession gaining tactics make an important contribution to conflict resolution (Jabri, 1995, 54). However, in the case of Kashmir, third parties have mostly complicated, rather than aided the prospects of a settlement. By taking advantage of the bi-polar Cold War order, Pakistan succeeded in presenting itself as an 'Islamic barrier again communism (Wirsing, 1994, 88). As Soviet Union launched its invasion of Afghanistan, Pakistan became a front-line state in the global ideological battle. This gave Pakistan access to billions of dollars of US military and economic aid, and although never threatening India's control of Kashmir, the military aid model largely undermined the fundamental asymmetry of the conflict denied India the chance to emerge as regional hegemon (Rudolph, 2008, 39). The end of the Soviet threat largely moved South Asia to the back burner in terms of US interest. However, following the 2001 terrorist attacks and the following 'War on Terror', Pakistan again has become a valuable ally for the US. Despite warnings from then deputy national security advisor Robert Gate that it would emerge as loser in any kind of full-scale military conflict, Pakistan has not reined its support for the Kashmir insurgency. A reason for this is arguably that these warnings tended to watered down by advices to Indian decision makers to step down their offensive and improve the human rights records of its security forces (Ganguly, 1997, 110111). Although, official statements from Washington have continued to urge Pakistan to stop aiding terrorist groups, its value in the 'War on Terror' has greatly reduced US pressure on Pakistan to resolve the Kashmir conflict (Bose, 2003, 227 / Bajpai, 2003, 114). Furthermore, as Pakistan also have sought ties with China, it has to a large extent confirmed Weiner's argument that as parties tend to seek support from countries with mutual interests, irredentist conflicts dictate patterns of alliance (Weiner, 1971, 671-2). Since the 1962 Sino-Indian war, China has at times given India more concerns than Pakistan; both as a main contributor to Pakistan's nuclear and missile program and as a potential enemy (Krepon, 2004, 28, 83).

By immediately blaming Pakistan as an 'agent provocateur' behind the insurgency, India has generally overlooked the possibility of multiple causes of popular discontent in the region (Ganguly, 1997, 226). However, looking at the recent decade, one can see some traces of progress, as Kashmir is no longer the battleground as it was during the 1990s (International Crisis Group 2010). Although both countries continuously refuse the idea of establishing the LoC into an international border; the 2004 'Composite talks' succeeded in reducing tensions and thereby prevented a return to the hostile climate of Kargil crisis (International Crisis Group 2006). Increased regional stability was further highlighted by the successful regional elections of 2002 and 2004, which largely restored popular belief in the possibility of free and fair elections. Since then, a coalition government have sought to cooperation but also qualified opposition to India (Dossani/Rowen, 2005, 255-257). Additional secret peace talk in 2007 further reduced cross boarder violence and created initial optimism. However, the inability to solve underlying issues again became highly visible as then President Pervez Musharraf lost grip to power and as the terrorist attack in Mumbai in 2008 efficiently put the 2004 initiated talks on hold (Polgreen 2010).

The 1998 introduction of mutual nuclear capability added yet another element to the conflict. Building on arguments raised by proliferation optimist such as Waltz; Hagerty (1990) argued in his study of the India-Pakistan conflict that "the logic of nuclear deterrence is more robust than the logic on nonproliferation" (Krepon, 2004, 70). On the contrary, as it can be argued that the India-Pakistan situation is significantly different, it is discussable whether the Cold War experiences are applicable to South Asia. This argument was further strengthened as the 2001-2002 Kargil conflict undermined two other common assumptions in international relations; democracies does not go to war against each other 
(the Nawaz Sharif government at the time was a civilian establishment), and that nuclear states does not go to war against each other. Although proliferation optimists will point out that in the postnuclear crisis of 1990, 1999, and 2001-2002; both parties restricted its military offensive, however, on the other hand it did not make the parties abstain from keeping their nuclear arsenals in status of advanced readiness (Krepon, 2004, 20, 25). Moreover, despite attracting international attention leading to a US led shuttle-diplomacy in the Kargil crisis; it did not lead to any sustained international effort (Basrur 2002). Combined with other fundamental differences such as asymmetric capability and short delivery times giving little time for considerations in an emergency, it is highly debatable if the introduction of nuclear weapons has improved the prospects of conflict resolution.

International analysts have frequently hailed domestic policies as important constraints for conflict resolution. As the conflict has become deeply embedded in the societal structures and identities, the prospect of any political leader in Pakistan or India to gather public support for giving up its claims seems distant (Bar-Tal, 2000, 351) (International Crisis Group 2003). Since the 1960s, Islamic radicalism has played a major role in Pakistani politics and by mixing identity with politics is has contributed to foment and sustain the Kashmir conflict (Dossani/Rowen, 2005, 2). As an example, the development of nuclear weapons which was framed as a necessary response to a threat to its national identity posed by India (Barash/Webel, 2009, 134). Despite failing to integrate 'Azad Kashmir, Islamic based ethno-nationalism has been vital to justify Pakistan's irredentist claims in Kashmir (Paul, 2005, 179) (Wirsing, 1994, 67). Although both countries have maintained relatively high military expenses, India's relative costs have not been on the level of Pakistan. Decades of constant conflict have left indelible marks on particularly Pakistan's political economy, where its centralized economy has throughout history been strongly oriented towards defence rather than development. These factors have left the military with a respected and privileged position in society, hence arguably being a benefiter of continued conflict in Kashmir (Jalal, 1995, 140-142). According to 'democratic peace theory', stable and consolidated democracies are less likely to resort to military force. As Pakistan's period of democracy have been short-lived, one cannot observe any impact on the Kashmir rivalry (Paul, 2005, 47-48).Continuous references to Kashmir as 'Indian-occupied Kashmir' and the 'unfinished business of the partition' has made it highly unlikely that any Pakistani government will be able to get acceptance for the idea of giving up on Kashmir without proving a significant concession from India (Bajpai, 2003, 121-122). As Pakistan has been struggling to maintain national unity, the Kashmir issue has and is likely to remain a live wire in Pakistani domestic policies and as a vital tool for ensuring government legitimacy (Sumit, 1997, 5) (Paul, 2005, 34).

\subsection{Objectives}

- To study the space provided to army event by local newspapers.

- To analyse portrayal of Indian Army in local newspapers.

\subsection{Hypotheses}

- At most of the times local newspapers under report army events.

- The newspapers portray Indian Army in negative way.

\subsection{Methodology}

For this study multiple methods have been employed, including content analysis and interview, besides personal observation by the researcher, who happens to be a journalist himself.

\subsection{Sample}

Under this study two major English newspapers of Kashmir have been selected based on their readership. The events concerning Indian Army carried by Greater Kashmir and Rising Kashmir were analysed during this study.

\subsection{Analyzing Categories}

In this research, the analyzing categories included language used, headlines, space provided, cartoons and pictures. 


\section{DISCUSSION}

During study, it was found that Kashmir media, especially print media remained critical to the presence of army in the region. The language used against army is highly provocative, like Greater Kashmir in its reports, refer Indian Army as 'government sponsored forces' and 'Indian oppressor forces', similarly Rising Kashmir always underreport the events of Army, while as in case of any civilian killing in cross firing, these newspapers shift blame on the army.

It was also found that very less space is being provided to the social welfare activities of the army in Kashmir. In one report, wherein Army conducted All India Tour for Kashmiri students, the newspapers provided it space on fourth page with most of the credit to civil administration.

Not only this, these newspapers also try to demean the Indian Army through pictures and cartoons. In one of the cartoons, the Greater Kashmir showed that before coming of army to Kashmir, the Kashmiris used to live inside their houses and army had to seek permission before entering their house, while as the other side of the cartoon showed that locals are waiting outside their houses, while as army stays inside. Meanwhile, the studied newspapers also do not give proper space to the army in case of death of any army personnel. In this study it was found that Greater Kashmir and Rising Kashmir had given entire profile of the slain militant, but the deaths of the army men remained conceded only in numbers.

In one of its report, the Greater Kashmir directly accused the Indian Army of killing an innocent shopkeeper, which according to national newspapers was involved in militancy activities.

Moreover, in one picture carried by Greater Kashmir , the Army has been made stock of criticism, wherein it has been shown that an army personnel is frisking a blind man.

In the conflict torn state, the image of Indian Army has been mutilated by the local newspapers. They not only underreport their achievements, but exaggerate events where army neutralise militants. The media accuses army of killing innocents.

\section{Conclusion}

In the conflict situation of Kashmir, the role of media becomes all important in generating an image of the Army. The newspapers moslty portray Indian Army as despotic, tyrant and human right violators.

Being himself working journalist, the researcher found that the newspapers deliberately instigate the readers about army by accusing army of human right violations. These newspapers mostly slip army events and sometimes distort the facts. For example, recently Indian army organised a function at terrorism infested Shoipan district to handover newly constructed all in one sports stadium to the locals. The event was a huge success and every one appreciated the efforts of the army in reaching out to the people, but media gave it different colour, some newspapers gave credit to civil administration, while as some termed it as a ploy to misguide youth.

While analysing the events, it has been seen that the reporters mostly are subjective in their reporting and blame Indian Army of excesses. Instead of highlighting the role of Indian Army in developing villages and borders of the state, the newspapers continue to harp negative side of the army and correlate them with the episodes of Kunanposhpora Mass rape case and other killings.

Admitting that newspapers cater as per wishes of their readers, a senior reporter working in Srinagar said that these newspapers cannot put actual image of the army as the reader doesn't want it.

The Kashmir's hate the Indian Army. They believe that Indian Army commits human rights violation and they mistreat the local population.

He said imposition of AFSPA would be another reason that people are so critical of the Army and Media adds fuel to the fire.

He said that you have to imagine something very basic to understand AFSPA. Imagine, your every walk and every breath is at the mercy of someone, who may randomly choose to enter your house and take you away never to be seen again. AFSPA (Armed Forces Special Powers Act), by its very name imparts "special powers" to the armed forces. If I were an armed soldier in Kashmir in 1990, and I felt, that a particular person eating apple does not seem good to me, I could just shoot the person away and be on my way. AFSPA has been especially written to allow a rule with an "iron rod". 
Meanwhile, the intentions of the army could be guaged from the fact that army chief General Dalbir Singh flew to Srinagar and Kupwara to be briefed by his top commanders on the situation after the reported molestation of a schoolgirl in Handwara and the killing of five civilians in the street protests and stone pelting that followed.

The army chief wanted to know: Do his soldiers face another season of violent street protests, like the three bloody summers at the end of the last decade: In 2008 over outgoing governor Lieutenant General S K Sinha (retd)'s ill-judged plan to acquire land for the Amarnath Yatra; in 2009 over eventually disproved allegations that the security forces had abducted, raped and murdered two local women in Shopian, in South Kashmir; and the worst in 2010, when over a hundred civilians were killed in months of street protests stemming from the murders of three civilians in a 'fake encounter' in Machhil, in North Kashmir.

The army's logic is simple: In the absence of a political dialogue with the separatists, public order remains unpredictable. Were the situation to spiral out of control, the army would not like to find itself without the shelter of AFSPA.

On the ground, the army continues to deal with growing public frustration, evident from swelling crowds at militants' funerals, and mobs throwing stones at soldiers battling cornered militants, but media sees only human right violations, when army retaliate.

\section{REFERENCES}

\section{BOOKS}

Barash, David P. / Webel, Charles P., (2009), Peace and Conflict Studies (2ed.), Sage Publications, London

Bose, Sumantra, (2003), Kashmir - Roots of conflict, Paths to Peace, Harvard University Press, Cambridge

Dossani, Rafiq / Rowen, Henry S. (ed.), (2005), Prospects for Peace in South Asia, Stanford University Press, Stanford

Ganguly, Sumit, (1997), The Crisis in Kashmir - Portents of War, Hopes of Peace, The Woodrow Wilson Center Press, Cambridge

Jalal, Ayesha, (1995), Democracy and Authoritarianism in South Asia - A comparative and historical perspective, Cambridge University Press, Cambridge

Krepon, Michael (ed.), (2004), Nuclear Risk Reduction in South Asia, Palgrave MacMillan, New York

Paul, T.V. (ed.), (2005), The India-Pakistan Conflict - An Enduring Rivalry, Cambridge University Press, New York

Rudolph, Lloyd I. / Rudolph, Susanne Hoeber (ed.), (2008), Making US Foreign Policy Towards South Asia - Regional Imperatives and the Imperial Presidency, Indiana University Press, Bloomington

Schofield, Victoria, (2000), Kashmir in Conflict - India, Pakistan and the Unfinished War, I.B. Tauris \& Co. Ltd., New York

Wirsing, Robert G., (1994), India, Pakistan, and the Kashmir Dispute - On Regional Conflict and Its Resolutions, MacMillan Press Ltd, London

\section{JOURNALS}

Bar-Tal, David, (2000), "From Intractable Conflict Through Conflict Resolution to Reconciliation: Psychological Analysis", Political Psychology, Vol. 21, No. 2, pp. 351-365

Blank, Jonah, (1999), “Kashmir: Fundamentalism Takes Root”, Foreign Affairs, Vol. 78, No. 6, pp. 36-53

Ganguly, Sumit, (2006), “Will Kashmir Stop India’s Rise?”, Foreign Affairs, Vol. 85, Issue 4

Jabri, Vivienne, (1995), "Agency, Structure, and the Question of Power in Conflict Resolution, Paradigms, Vol. 9, No. 2, pp. 53-70

Kilcullen, David, (2006), “Counter-insurgency Redux”, Survival, 48: 4, pp. 111 - 113

Weiner, Myron, (1971), "The Macedonian Syndrome: An Historical Model of International Relations and Political", World Politics, Vol. 23, No. 4 pp. 665-683 


\section{ELECTRONIC SOURCES}

International Crisis Group, (2003), "Kashmir: Learning from the Past, Asia Report No70, 4 December”,http://www.crisisgroup.org/en/regions/asia/south-asia/kashmir/070-kashmirlearning-from-the-past.aspx

International Crisis Group, (2005), "India/Pakistan Relations and Kashmir: Steps toward Peace", Asia Report No.79, 24.June, Accessed at 16.11.2010 at http://www.crisisgroup.org/ en/regions/ asia/south-asia/kashmir/079-india-pakistan-relations-and-kashmir-steps-toward-peace.aspx

International Crisis Group, (2006), "India, Pakistan and Kashmir: Stabilizing a Cold Peace", Asia Briefing No. 51, Accessed on 10.11.2010 at http://www.crisisgroup.org/en/regions/asia/southasia/kashmir/B051-india-pakistan-and-kashmir-stabilising-a-cold-peace.aspx

International Crisis Group, (2010), "Steps towards Peace: Putting Kashmiris First", Asia Briefing No.1063, Accessed on 16.11.2010 at http://www.crisisgroup.org/en/regions/asia/southasia/kashmir/B106-steps-towards-peace-putting-kashmiris-first.aspx

Polgreen, Lydia, (2010), "Indian Forces Face Broader Revolt in Kashmir", Accessed at 11.11.2010 at http://www.nytimes.com/2010/08/13/world/asia/13kashmir.html?pagewanted=2\&_r=2

\section{NEWSPAPERS}

Greater Kashmir (www.greaterkashmir.com)

Rising Kashmir (www.risingkashmir.com)

Kashmir Reader (www.kashmirreader.com) 